JIKSH: Jurnal Ilmiah Kesehatan Sandi Husada
https://akper-sandikarsa.e-journal.id/JIKSH
Volume 10| Nomor 1| Juni|2021
e-ISSN: 2654-4563 dan p-ISSN: 2354-6093
DOI 10.35816/jiskh.v10i1.512

Literature Review

\title{
Hubungan antara Konsumsi Ikan Asin dengan Karsinoma Nasofaring
}

\section{Retno Julianingrum}

Fakultas Kedoktaran, Universitas Lampung

\begin{tabular}{|c|c|}
\hline Article Info & Abstract \\
\hline $\begin{array}{l}\text { Article History: } \\
\text { Received:28-01-2021 } \\
\text { Reviewed:20-02-2021 } \\
\text { Revised:06-03-2021 } \\
\text { Accepted:22-04-2021 } \\
\text { Published:30-06-2021 }\end{array}$ & $\begin{array}{l}\text { Abstrak. Pengantar; karsinoma nasofaring (NPC) adalah } \\
\text { keganasan paling umum pada telinga, hidung, dan tenggorokan } \\
\text { (THT). Tujuannya adalah untuk mengetahui hubungan antara } \\
\text { konsumsi ikan asin dengan karsinoma nasofaring. Metode; } \\
\text { Pencarian artikel dilakukan di PubMed® dengan kata kunci } \\
\text { terkait dan kemudian disaring sesuai dengan kriteria inklusi dan } \\
\text { eksklusi. Sehingga kami mendapatkan enam artikel yang } \\
\text { relevan untuk penilaian kritis. Hasil; bahwa hubungan antara } \\
\text { konsumsi ikan asin dan karsinoma nasofaring tidak konsisten. } \\
\text { Kesimpulan; perbedaan dalam kejadian karsinoma nasofaring } \\
\text { dan ikan asin yang dimakan pada populasi berbeda mungkin } \\
\text { telah berkontribusi pada hasil yang tidak konsisten ini. Untuk } \\
\text { menemukan bukti yang lebih baik, kami merekomendasikan } \\
\text { penggunaan tinjauan sistematis. } \\
\text { Abstract. Introduction; nasopharyngeal carcinoma (NPC) is the } \\
\text { most common malignancy of the ear, nose and throat (ENT). } \\
\text { Aim was to determine the relationship between salted fish } \\
\text { consumption and nasopharyngeal carcinoma. Method; Search } \\
\text { for articles was carried out in PubMed® with related keywords } \\
\text { and then filtered according to inclusion and exclusion criteria. } \\
\text { So that we get six articles that are relevant for a critical } \\
\text { assessment. Result; that the association between salted fish } \\
\text { consumption and nasopharyngeal carcinoma was inconsistent. } \\
\text { Conclusion; differences in the incidence of nasopharyngeal } \\
\text { carcinoma and salted fish eaten in different populations may } \\
\text { have contributed to this inconsistent outcome. To find better } \\
\text { evidence, we recommend the use of a systematic review. }\end{array}$ \\
\hline $\begin{array}{l}\text { Corresponding author } \\
\text { Email }\end{array}$ & $\begin{array}{l}\text { Retno Julianingrum } \\
\text { retnojulya@gmail.com }\end{array}$ \\
\hline
\end{tabular}

\section{Pendahuluan}

Karsinoma nasofaring (KNF) merupakan keganasan tersering pada bagian telinga, hidung dan tenggorokan (THT). Sampai saat ini, ada perbedaan geografis dalam prevalensi KNF dimana etnis Asia, termasuk Asia Tenggara, memiliki risiko KNF yang lebih tinggi. Di indonesia, KNF merupakan tumor yang paling umum ke-4 yang dialami oleh pria dengan insidensi sekitar 6/100.000 orang per tahun, meskipun secara global, KNF dianggap sebagai keganasan yang langka dengan insidensi yang rendah (sekitar 1/100 000 orang per tahun). Diagnosis dianggap sulit dan seringkali pasien datang pada stadium akhir penyakit (Adham M, Kurniawan AN, Muhtadi AI, et al, 2012). 
Beberapa penelitian melaporkan bahwa selain virus Epstein Barr, faktor host, genetik, dan lingkungan dapat mempengaruhi angka insidensi tesebut. Salah satu faktor lingkungan yang diduga dapat memiliki hubungan dengan keganasan ini adalah konsumsi ikan asin, dimana kandungan $\mathrm{N}$-nitrosamine diduga memiliki peran terhadap timbulnya KNF (Chou J, Lin YC, Kim J, et al, 2008; Ghaly AE, Ramakrishnan VV, Brooks MS, Budge SM, Dave D, 2013; Jia WH, Qin HD, 2012). Pengolahan tradisional ikan laut dengan pengeringan dan penggaraman dianggap sebagai salah satu metode yang aman dan hemat biaya untuk memenuhi kebutuhan protein harian. Oleh karena itu, pengetahuan tentang efek konsumsi ikan asin dalam jangka panjang, terutama kaitannya dengan KNF sangat penting (Mary D, Saritha K, Jansi, 2013). Tujuan mengetahui hubungan antara konsumsi ikan asin dengan karsinoma nasofaring.

\section{Metode}

Pencarian literatur dilakukan di database PubMed $^{\circledR}$ pada 05 Oktober 2020 dengan memasukkan kata kunci "salted fish" dan "nasopharyngeal carcinoma". Kami kemudian mengatur pemilihan artikel lebih lanjut dengan kriteria: Publikasi 10 tahun terakhir, subjek manusia, dan penelitian yang dilakukan pada populasi dewasa (lebih dari 19 tahun). Penelitian ini merupakan penelitian studi pustaka (literature review) dengan melakukan telaah pustaka pada artikel yang relevan dengan tujuan penelitian. Studi pustaka pada penelitian ini dilakukan dengan melakukan telaah sistematis pada artikel yang sesuai dengan kriteria inklusi dipublikasikan secara nasional maupun internasional dalam periode publikasi 10 tahun terakhir. Artikel yang sesuai dengan kriteria inklusi kemudian akan dipilah sesuai dengan tujuan penelitian serta isi artikel secara keseluruhan untuk memastikan artikel benar-benar relevan dengan penelitian ini. Artikel yang sesuai akan ditelaah secara keseluruhan untuk diringkas dan disajikan pada penelitian ini untuk menjawab tujuan penelitian.

\section{Hasil Dan Pembahasan}

Setelah melakukan penelusuran literatur di database tersebut, kami menemukan 111 artikel yang terkait. Tujuh belas artikel cocok dengan strategi pencarian menggunakan kriteria seperti yang dijelaskan di atas. Setelah ditelusuri lebih lanjut, ada enam artikel yang relevan yaitu : Ekburanawat et al, Jia et al, Ren et al, Guo et al, Yang et al, dan Hsu et al. Keenam artikel tersebut valid berdasarkan aspek penilaian kritis validitas. Semua studi yang dimasukkan adalah case control dan menggunakan kuesioner untuk mengingat kebiasaan makan ikan asin subjek. Jia et al dan Ren et al melakukan studi kasus kontrol untuk mengevaluasi hubungan antara pola makan tradisional suku Kanton dan KNF, salah satu makanan utama yang diteliti adalah ikan asin. Pada penelitian Jia et al, kelompok kasus diambil dari pasien rumah sakit yang dikonfirmasi dengan pemeriksaan histopatologi dengan kelompok kontrol dari pasien umum di rumah sakit yang sama dan dicocokkan berdasarkan jenis kelamin, usia, dialek, dan tempat tinggal. Dalam penelitian tersebut, didapatkan hasil berupa subjek dengan konsumsi ikan asin rutin setiap bulannya memiliki risiko lebih tinggi terhadap KNF (OR 2.42, CI 95\%: 1.65-3.54).

Sedangkan pada penelitian Ren et al dilakukan studi kasus kontrol untuk mengetahui faktor lingkungan yang dikaitkan dengan KNF pada pasien dengan riwayat keluarga sebelumnya dengan salah satu paparan adalah konsumsi ikan asin. Kelompok kasus adalah pasien KNF yang didiagnosis di pusat kanker, tinggal di Guangdong setidaknya selama lima tahun dan tidak memiliki riwayat kanker lain dengan kelompok kontrol adalah pasien pemeriksaan umum dan disesuaikan untuk jenis kelamin, usia dan tempat tinggal. Dalam penelitian ini, terdapat peningkatan resiko KNF pada konsumsi rutin ikan asin minimal satu bulan (adjusted OR 2.54, CI 95\%: 2.20-2.94). Penelitian Guo et al melakukan studi kasus kontrol untuk menyelidiki hubungan antara faktor risiko non virus dan KNF pada populasi berisiko tinggi di Guangdong, Cina Selatan. Seperti penelitian sebelumnya, kelompok kasus 
diambil berdasarkan konfirmasi pemeriksaan histopatologi KNF sementara kelompok kontrol adalah orang sehat yang disesuaikan dengan usia, jenis kelamin dan tempat tinggal. Penelitian ini juga menegaskan bahwa konsumsi ikan asin lebih dari tiga kalu dalam sebulan merupakan salah satu faktor resiko KNF (adjusted OR 1,90, CI 95\%: 1.05-3.47). Menurut (Rahman et al., 2015) berpendapat bahwa pembuktian secara klinis dan ilmiah terhadap faktor nonviral sebagai penyebab timbulnya karsinoma nasofaring masih belum dapat dijelaskan secara pasti. Faktor nonviral merupakan salah satu faktor risiko yang dapat meningkatkan angka kejadian timbulnya keganasan nasofaring.

Namun, penelitian Yang et al, Hsu et al, dan Ekburanawat et al menunjukan hasil yang bertentangan dengan ketiga penelitian diatas. Penelitian Yang et al. melakukan studi case control pada orang berisiko tinggi yang tinggal di Taiwan. Bahkan pada masyarakat dengan konsumsi ikan asin lebih dari satu kali dalam seminggu, tidak ada hubungan antara konsumsi ikan asin dengan KNF dengan OR 1,78 CI 95\%: 0,82-3,89. Sejalan dengan penelitian Yang et al, Hsu et al.13 melakukan studi juga di Taiwan dengan kelompok kasus yang diambil dari pasien KNF yang telah didiagnosis dan dikonfirmasi oleh pemeriksaan histopatologis. Di dalam penelitian ini ditegaskan bahwa konsumsi ikan asin lebih dari tiga kali sebulan tidak berhubungan dengan KNF (disesuaikan OR 0.88, CI 95\%: 0.35-2.21). Sedangkan Ekburanawat et al melakukan studi pada populasi Thailand dari National Cancer Institute di Bangkok dan menyatakan bahwa tidak ada hubungan antara konsumsi ikan asin dengan KNF (adjusted OR1.38, CI 95\%: 0.84-2.25). Dari keenam penelitian diatas, ditemukan hasil yang tidak konsisten terkait dengan hubungan konsumsi ikan asin dan KNF. Bahwa pola pada penderita karsinoma pankreas berdasarkan umur, jenis kelamin, prosedur, ikterus, atau bukan ikterus dan predileksi (Via et al., 2020). Karakteristik histopatologi dan stadium klinis kanker nasofaring, distribusi frekuensi kanker nasofaring berdasarkan jenis kelamin dan umur (Kuswandi et al., 2020).

Diduga, terdapat tiga faktor yang berhubungan dengan KNF: virus Ebstein-Barr, genetik, dan faktor lingkungan. Meskipun insiden di seluruh dunia untuk KNF cukup rendah, namun beberapa negara di benua Asia memiliki insiden yang relatif lebih tinggi, terutama di Cina Selatan dan Asia Tenggara (Ganguli NK, Satyanarayana K, Srivastava VK, et al , 2014). Di Cina Selatan, insiden KNF sangat tinggi. Jia et al, Ren et al, dan Guo et al, secara jelas menunjukkan bahwa terdapat hubungan yang signifikan antara konsumsi ikan asin dengan KNF pada populasi tersebut (Guangdong). Namun, tiga penelitian lain tidak menunjukkan hubungan tersebut. Menurut (Kasim et al., 2020) berpendapat bahwa ada hubungan yang signifikan antara konsumsi ikan dan daging asap dengan kejadian karsinoma nasofaring. Kanker sulit didiagnosis pada tahap awal dan umumnya memiliki prognosis yang buruk. Reseksi bedah adalah satusatunya pengobatan yang berpotensi menyembuhkan karsinoma (Hanriko, 2019). Menurut Ada hubungan antara konsumsi ikan asin dengan kejadian nasofaring di bagian otolaryngeal-head and neck (Kurniasari et al., 2020).

\section{Simpulan Dan Saran}

Bahwa hubungan antara konsumsi ikan asin dan karsinoma nasofaring tidak konsisten. Hubungan tersebut hanya terlihat pada penelitian yang dilakukan di Cina Selatan, di mana kejadian karsinoma nasofaring sangat tinggi dan ikan asin yang dikonsumsi. Perbedaan kejadian karsinoma nasofaring dan ikan asin yang dimakan pada populasi berbeda mungkin dapat berkontribusi pada hasil yang tidak konsisten ini. 
JIKSH: Jurnal Ilmiah Kesehatan Sandi Husada

Volume 10 Nomor 1 Juni 2021

\section{Daftar Rujukan}

Adham M, Kurniawan AN, Muhtadi AI, et al. 2012. Nasopharyngeal carcinoma in Indonesia: epidemiology, incidence, signs and symptoms at presentation. Chin J Cancer; 31(4):18596.

Chou J, Lin YC, Kim J, et al. 2008. Nasopharyngeal carcinoma--review of the molecular mechanisms of tumorigenesis. HeadNeck.;30(7):946-63.

Ekburanawat W, Ekpanyaskul C, Brennan P, et al. 2010. Evaluation of non-viral risk factors for nasopharyngeal carcinoma in Thailand: results from a case-control study. Asian Pac $\mathbf{J}$ Cancer Prev.11(4):929-32.

Ghaly AE, Ramakrishnan Hanriko, R. (2019). Mesothelin Sebagai Biomarker Deteksi Dini Kanker Pankreas. Jurnal Ilmiah Kesehatan Sandi Husada, 10(2), 143-150.

Kasim, M., Tan'im, T., Pebriyani, U., \& Aprillya, E. (2020). Konsumsi Ikan Asin dan Daging Asap dengan Kejadian Karsinoma Nasofaring. JIKSH: Jurnal Ilmiah Kesehatan Sandi Husada, 9(1 SE-Articles). https://doi.org/10.35816/jiskh.v11i1.220

Kurniasari, I., Kurnia, E., \& Tamzil, N. S. (2020). Hubungan Kebiasaan Konsumsi Ikan Asin Dengan Kejadian Karsinoma Nasofaring Di Departemen Tht-Kl Rsup Dr. Mohammad Hoesin Palembang. Sriwijaya University.

Kuswandi, A., Kuswandi, N. H., Kasim, M., \& Wulandari, M. (2020). Karakteristik Histopatologi dan Stadium Klinis Kanker Nasofaring. Jurnal Ilmiah Kesehatan Sandi Husada, 11(1), 243-251.

Via, F., Erianto, M., \& Wulandari, M. (2020). The Pattern in Patients with Carcinoma. JIKSH: Jurnal Ilmiah Kesehatan Sandi Husada, 9 (2 SE-Articles). https://doi.org/10.35816/jiskh.v12i2.393

Rahman, S., Budiman, B. J., \& Subroto, H. (2015). Faktor risiko non viral pada karsinoma nasofaring. Jurnal Kesehatan Andalas, 4(3).

Ren ZF, Liu WS, Qin HD, et al. 2010. Effect of family history of cancers and environmental factors on risk of nasopharyngeal carcinoma in Guangdong, China. Cancer Epidemiol 34(4):419-24.

Via, F., Erianto, M., \& Wulandari, M. (2020). The Pattern in Patients with Carcinoma. JIKSH: Jurnal Ilmiah Kesehatan Sandi Husada, 9(2 SE-Articles). https://doi.org/10.35816/jiskh.v12i2.393

VV, Brooks MS, Budge SM, Dave D. 2013. Fish processing wastes as a potential source of proteins, amino acids, and oils: A critical review. J Microb Biochem Technol 5(4):10729.

Yang XR, Diehl S, Pfeiffer R, et al. 2005. Evaluation of risk factors for nasopharyngeal carcinoma in high-risk nasopharyngeal carcinoma families in Taiwan. Cancer Epidemiol Biomarkers 14(4):900-5. 